\title{
Mengkritisi Fenomena Korupsi di Parlemen
}

\author{
Oleh: Artidjo Alkostar \\ Hakim Agung Mahkamah Agung RI \\ e-mail:artidjo@fh.uii.ac.id
}

\begin{abstract}
Corruption eradication requires not mere technological hardware and good legal enforcement institutions, but this again, requires software instrument in the form of legal culture, which encompasses the ideology of law and the ideology which legal apparatus adopt. More importantly, in this globalization era, corruption prevention interconnects with politics, economics, culture, law, and international world. Two elements, namely social-political control, as well as penalization which is derived from the ideal concept of justice, are key elements in this regard.
\end{abstract}

Keywords: Korupsi, Parlemen

\section{Pendahuluan}

Dalam era globalisasi korupsi telah menjadi fenomena kejahatan yang menyangkut hubungan multilateral dan internasional. Apalagi yang berkualifikasi korupsi politik modus operandi dan implikasinya lebih komplek dibandingkan dengan korupsi yang dilakukan oleh orang biasa yang tidak memiliki kekuasaan politik. Korupsi politik yang dilakukan oleh pejabat tinggi di suatu negara juga terjadi di berbagai negara di semua benua. Korupsi politik memiliki dampak negatif yang merusak tata kehidupan negara dan melanggar hak dasar rakyat di negara yang bersangkutan.

Korupsi di Indonesia seperti halnya juga di beberapa negara lain, banyak berkorelasi dengan penyalahgunaan kekuasaan dari para pemegang kekuatan politik. Watak kekuasaan pada dasarnya berambisi untuk memperbesar pengaruh, memperluas jangkauan dan cengkeramannya terhadap rakyat yang seringkali tidak memiliki kekuatan kontrol yang signifikan terhadap geliat kekuasaan yang selalu merambat. Di dalam negara modern, kontrol rakyat terhadap 
kekuasaan dapat berupa kontrol politik, sosial maupun yuridis, dengan berbagai variasi corak aplikasinya yang legitimate. Kekuasaan sentralistik dari rezim Orde Baru menunjukkan adanya jalinan hubungan yang sistemik antara pemegang kekuasaan politik dengan pemegang kekuatan ekonomi. Hubungan penyalahguna, penjaja, makelar kekuatan politik dengan konglomerat yang tidak otentik (banyak konglomerat 'karbitan') itu berpilin berkelindan secara kolutif dan tanpa adanya kontrol hukum yang memadai. Dari adanya hubungan ilegal antara kekuatan politik yang liar dan kekuasaan ekonomi yang rakus, terjadilah di Indonesia krisis ekonomi serta ambruknya keuangan negara yang sangat parah dan dirasakan hingga saat ini.

Pemegang kekuasaan politik biasanya "ketagihan" untuk tetap berkuasa dan tidak mau melepaskan kekuasaan yang telah dipegangnya. Untuk mempertahankan kekuasaannya penguasa biasanya memperkuat basis pendukung yang diukur dengan kadar loyalitas para kroni. Bentuk dukungan bisa berupa massa berkekuatan fisik, dukungan ekonomis atau money politics, dukungan pemikiran strategi dan teknik mempertahankan kekuasaan, dukungan spiritual, atau dukungan hukum. Bagi yang tidak loyal kepada penguasa korup, baik itu individu maupun kelompok, si penguasa akan membuat batas pembeda dengan cara membuat stigma politik, menjatuhkan persona non grata, atau menjebloskan ke penjara dengan mempergunakan rekayasa peradilan sesat. Dalam arti pula penguasa yang korup, biasanya mempermainkan kuasa dengan cara membuat orang atau kelompok yang tidak disenangi karena bersikap kritis, berbeda pendapat atau dianggap menentang, dibuat dalam posisi merasa bersalah, merasa malu, terkucil, terintimidasi, terteror, atau terbujuk (terangkul). Kekuasaan politik yang korup berimplikasi terhadap timbulnya pelanggaran hak asasi manusia (HAM) dan munculnya sikap ABS (Asal Bapak Senang) serta tingkah laku hipokrit.

Dari sikap ABS dalam kekuasaan pemerintahan yang korup, akan muncul jual-beli proteksi, artinya seseorang atau kelompok baru akan merasa aman secara politik atau ekonomi, kalau dekat dengan lingkaran kekuasaan. Hubungan transaksional antara penjual jasa proteksi perkara, sehingga menimbulkan penganiayaan, penculikan, penyekapan dan sebagainya, yang melanggar HAM, disebut "kesalahan prosedur."1) Penghalusan yang bermotif membiasakan makna arti suatu

${ }^{1}$ Romli, usep, H, HM, Hapus Budaya Pengahalusan , HKM, IV, Juli 1998 
istilah, term atau kata yang dilakukan oleh pihak yang berkuasa merupakan bagian dari upaya atau rekayasa menutupi praktek korupsi politik yang dilakukan oleh rezim tersebut. Secara tersamar juga terlihat adanya upaya mengelabui pandangan rakyat terhadap berbagai corak penyimpangan moral politik dan hukum yang orang atau kelompok yang sedang memegang kekuasaan.

Adanya kompleksitas permasalahan tentang korupsi politik di atas, tulisan ini hendak mengkaji upaya apa saja yang diperlukan untuk menanggulangi korupsi politik di Indonesia.

\section{Korupsi di Parlemen}

Korupsi di Parlemen merupakan korupsi politik yang sifat berbahayanya lebih dahsyat dari korupsi yang dilakukan oleh orang yang tidak memiliki kekuasaan politik. Begitu pula dampak sosial-ekonominya, sehingga memerlukan upaya penegakan hukum khusus dalam penanggulangannya. Secara historis, korupsi politik telah banyak meruntuhkan negara menuju kehancuran dan menenggelamkan bangsa ke lembah kenistaan dan menyeret pelakunya ke sudut kehinaan. Korupsi politik yang terjadi di Parlemen merupakan salah satu bentuk pengkhianatan terhadap amanah rakyat dengan cara memperjual-belikan kekuasaan elektoral demi keuntungan pribadi atau kelompok.

Kekuasaan dalam negara modern sebagai manifestasi dari kekuasaan rakyat, sejatinya merupakan amanah rakyat kepada pemegang kekuasaan negara untuk dilaksanakan sesuai dengan tujuan kehidupan bernegara. Penyimpangan pelaksanaan kekuasaan secara moral dan hukum merupakan korupsi kekuasaan. Dengan demikian, entitas korupsi politik melekat secara berpilin berkelindan dengan praktek pelaksanaan kekuasaan. Dalam aplikasinya perbuatan korupsi kekuasaan itu muncul dalam berbagai corak dan variasinya, karena terkait dengan jenis dan tingkat penyalahgunaan wewenang, kesepakatan, dan sarana yang melekat pada jabatan atau kedudukan penguasaan politik.

Korupsi yang dilakukan oleh anggota Parlemen merupakan korupsi politik yang mengkhianati rakyat, khususnya konsisten pendukungnya dan pada saat yang bersamaan akan menurunkan kredibilitas personal dan institusional. Korupsi politik di Parlemen merugikan perjalanan politik bangsa Indonesia, karena wakil rakyat yang memiliki mandat kekuasaan elektoral yang harus profesional membangun visi misi depan bangsa dibelokkan menjadi pelaku transaksional yang kolutif. Anggota Dewan 
Perwakilan Rakyat (DPR) Pusat maupun Daerah merupakan representasi dari rakyat pemilihnya, sehingga jika terlibat korupsi, akan melukai rasa keadilan masyarakat pemilihnya, dan pada gilirannya berdampak negatif bagi sensitifitas moral bangsa.

Fenomena korupsi di Parlemen pada dasarnya melekat pada sistem pelaksanaan kekuasaan politik, sehingga entitasnya bersifat sistemik. Berbeda dengan korupsi biasa, korupsi politik berkualifikasi structural corruption (Korupsi struktural). Sejak Orde Baru, pemerintah cenderung menyelesaikan korupsi politik dengan cara menyembunyikan di bawah karpet (to sweep in under the carpet). Sikap demikian tidak lepas dari watak dasar korupsi politik yang merupakan bagian dari mesin kekuasaan. Kekuasaan politik anggota parlemen sejatinya bukan dimiliki, tetapi merupakan titipan atau amanah dari rakyat. Kekuasaan elektoral anggota Parlemen hanya merupakan artefak yang tidak pernah dimiliki selamanya oleh pemegangnya (anggota parlemen). Dalam negara Indonesia yang demokratis egaliter, tidak ada tempat sakral bagi institusi atau orang yang kebal hukum dan ditabukan dari kontrol moral serta kritik sosial politik. Uang negara yang dikorup oleh anggota Parlemen adalah uang rakyat yang seharusnya dikelola dan dipergunakan bagi kemakmuran rakyat.

Fenomena terkuaknya legislator yang korup di Parlemen harus dijadikan petunjuk bagi bangsa Indonesia untuk terus mengibarkan bendera perang terhadap korupsi. Lembaga legislatif dan anggota Parlemen merupakan figur dan representasi dari rakyat Indonesia, sehingga korupsi yang terjadi di lembaga negara tersebut, harus direspon baik secara penal maupun nonpenal, agar fenomena sikap korupsi tidak dianggap sebagai konvensi atau kebiasaan umum dalam tingkah laku politik di Indonesia. Di samping secara bersamaan rakyat secara kritis harus juga merespon secara politis yaitu tidak memilih atau memilih kembali anggota parlemen yang korup. Istilah korupsi harus dikembalikan ke dalam habitatnya yaitu perbuatan korupsi dan keruptor sebagai pencuri uang rakyat yang harus selalu dijadikan musuh bersama rakyat.

Fenomena korupsi yang dilakukan oleh pemegang kekuasaan elektoral atau anggota parlemen, merupakan bagian dari upaya memperkuat atau mendapatkan pengakuan politik dengan memperbesar kekayaan ekonomis. Salah satu modus operansi membangun citra diri sebagai politikus adalah dengan melakukan hubungan transaksional illegal. Hubungan tersebut biasanya berlangsung secara rahasia, tidak transparan dan bersifat kolutif antara pemegang amanat rakyat dengan pengusaha 
yang asosial atau pihak lain, yang akan menimbulkan ketidakadilan ekonomi dan politik. Praktek tindakan korupsi demikian juga berimplikasi dalam teknik pembuatan dalam proses peradilan pidana.

Praktek korupsi di Parlemen menunjukkan adanya sikap ketidakjujuran pada sebagian politisi. Sebagaimana dielaborasi oleh Noreena Hertz yang antara lain mengatakan: ${ }^{2}$ Politicians are increasingly seen as imptent, irrelevant, and dishonest. People see their governments as unable to deliver what their promise, obsessed with unimportant issues and internal politicking riddled with corruption, clinging to outmoded nations of authority, and increasingly in the pocked of business people. The distinction between incompetence and dishonesty is becoming blurred as, in country after country, senior politicians are discovered to have angaged in corrupt practices. Jadi korupsi di kalangan pemegang kekuasaan politik, menimbulkan kaburnya antara ketidakmampuan dan ketidakjujuran di mata rakyat.

Dalam telaahnya tentang korupsi di Parlemen, Amartya Sen mengemukakan contoh di Parlemen Italia dengan juga memunculkan istilah "relative justice" untuk menunjuk pada tingkah laku yang berpedoman "orang lain juga melakukan seperti itu". A sense of 'relative justice' visa-a-vis a compration group (in particular, others similarly placed) can be an important influence on behavior. Inded, the argument that "others do the same" was one of the more commonly cited "rason" for corrupt behavior found in the Italian parliamentary inquiry that looked into the linkage between corruption and the Mafia in 1993. ${ }^{3}$

Praktek korupsi dan skandal lainnya di Parlemen juga terjadi di Amerika Serikat, seperti ditulis oleh Stanley G. Hilton \& DR. Anne-Renee Testa, dalam bukunya Glass Houses, Shocking Profiles of Corgressional Sex Scandals and Other Unofficial Misconduct, yang memaparkan tingkah laku menyimpang dari 38 anggota konggres Amerika Serikat. Hal ini menunjukkan penyakit kanker korupsi politik dapat menyerang anggota parlemen di yang paling maju dala bidang ekonomi dan teknologi, karena korupsi juga menyangkut faktor mental dan rohani individu. ${ }^{4}$

\footnotetext{
${ }^{2}$ Noreena Hertz, Global Capitalism and Death of Democracy, the Silent Takeover, HarperCollins Publishers Inc. New York, 2003.

${ }^{3}$ Sen Amartya, Development As Freedom, Anchor Books, New York, 1999.

${ }^{4}$ Stanley G. Hilton \& DR. Anne-Renee Testa, Glass Houses, Shocking Profiles of Corgressional Sex Scandals and Other Unofficial Misconduct, St Martin's Paperbacks, New York, 1998. Lihat dalam Artidjo Alkostar, Korupsi Politik Di Negara Modern, FH UII Press, Yogyakarta, 2008, Hlm. 241.
} 
Secara historis korupsi politik dapat meruntuhkan negara yang paling perkasa sekalipun. Sejak raja Babilonia Hammurabi pasca tahun 1600an Sebelum Masehi sebagai pembuat Undang-undang tertulis pertama di dunia telah memuat larangan praktek suap. Seperti Edward Gibbon dalam bukunya yang monumental The History of the Decline and Fall of the Roman Empire yang memaparkan keruntuhan imperium kerajaan Romawi karena merajalelanya praktek korupsi. Demikian juga Alessandro Barbero, dalam bukunya The Day of The Barbarians, The battle that Led To The Fall of The Roman Empire, antara lain memaparkan: Corruption was endemic in the Roman Empire, and the entire system of contracts and supplies for the army had always offered unlimited opportunities for criminal gain. ${ }^{5}$

Di Indonesia sendiri secara historis, korupsi telah terjadi sejak zaman VOC, pada awal kemerdekaan, masa Orde Lama, Orde Baru, Masa Reformasi hingga saat ini. Telah banyak perangkat hukum dan perundang-undangan diberlakukan, tetapi intensitas dan kualitas kejahatan korupsi tetap meningkat. Cita-cita kemerdekaan dan tujuan reformasi dihadang oleh deretan koruptor baik yang berada dalam kekuasaan negara yang culas maupun pengusaha yang rakus. Untuk itu perlu diperbanyak dan dirapatkan barisan anti korupsi agar tiang Negara menjadi tegak dan bermartabat. Pasal 41 UU No. 31 Tahun 1999 tentang Tindak Pidana Korupsi telah ditentukan adanya peran masyarakat. Ketentuan ini membuka peluang bagi masyarakat untuk memberikan kontribusi peran sosial dalam upaya pemberantasan korupsi, sehingga tercapai keadaan masyarakat yang tidak ada toleransi (zero tolerance) terhadap segala bentuk korupsi yang selalu menggerogoti tiang negara dari dalam. Segala bentuk trik yang mencampur-adukkan antara yang haq dan yang bathil, sikap permissif terhadap suap, ambivalensi dalam mensikapi suap dan lain sejenisnya harus dikikis, agar atmosfir kehidupan bernegara menjadi bersih dari polusi tindakan koruptif.

\section{Karakteristik Tindak Pidana Korupsi}

Secara yuridis formulasi tindak pidana korupsi terlihat dalam konstruksi hipotesis pasal-pasal undang-undang tindak pidana korupsi dengan segala perubahan dan perkembangannya. Telah banyak kajian

${ }^{5}$ Alessandro Barbero, The Day of The Barbarians, The battle that Led To The Fall of The Roman Empire, Walker \& Company, New York, 2005. 
tentang faktor-faktor penyebab korupsi dan akibatnya, begitu pula tentang tipologi dan pola-pola penaggulangannya baik secara nasional maupun internasional. Di sisi lain, seorang psikiater dari rumah sakit Jiwa Magelang, dr. Wildan $\mathrm{SpKj}{ }^{6}$ pernah mengatakan bawha korupsi merupakan puncak penyakit rohani. Orang yang sehat jiwanya, belum tentu rakhaninya juga sehat. Contohnya koruptor, penyandang sakit rokhani yang jiwanya tetap sehat. Otaknya jalan. Untuk bisa korupsi butuh kepintaran, bagaimana cara menyusun taktik, dan orang yang bisa "dibeli" termasuk sakit rokhani. Dan itu patut di kutuk. Sedangkakan kalau penderita sakit jiwa jangan dipojokkan. Kalau mengecam, orang yang sakit rokhani itu, para koruptor.

Hubungan kejahatan korupsi dengan politik, budaya dan ekonomi dapat bersifat korelasional dan menimbulkan akibat multi dimensi. Terutama korupsi politik (political corruption) yang juga biasanya menimbulkan akibat dahsyat bagi hak asasi manusia.

Kelahiran Undang-Undang No. 30 Tahun 2002 tentang Komisi Pemberantasan Tindak Pidana Korupsi tidak lepas dari postulat moral yang melatar belakanginya. Dalam penjelasan umum UU No. 33 Tahun 2002 antara lain dijelaskan: meningkatnya tindak pidana korupsi yang tidak terkendali akan membawa bencana tidak saja terhadap kehidupan perkonomian nasional tetapi juga pada kehidupan berbangsa dan bernegara pada umumnya. Tindak pidana yang meluas dan sistematis juga merupakan pelanggaran terhadap hak-hak sosial dan hak-hak ekonomi masyarakat, dan karena itu semua maka tindak pidana korupsi tidak lagi dapat digolongkan sebagai kejahatan biasa melainkan telah menjadi suatu kejahatan luar biasa. Begitupun dengan upaya pemberantasannya tidak lagi dapat dilakukan secara biasa tetapi dituntut cara-cara yang luar biasa. Sebagai lembaga yang tidak konvensional KPK (Komisi Pemberantasan Korupsi) memiliki misi khusus bagi penegakan hukum secara luar biasa yang mempunyai kewenangan luas, independen serta bebas dari kekuasaan manapun dalam upaya pemberantasan tindak pidana korupsi, yang pelaksanaannya dilakukan secara optimal, intensif, efektif, profesional serta berkesinambungan.

Meningkatnya kejahatan korupsi yang diikuti bertambahnya jumlah kerugian keuangan negara atau perekonomian negara menjadi bagian 2007

${ }^{6}$ Kedaulatan Rakyat, Minggu Pagi, No. 33 tahun ke-60an Minggu II November 
dari latar belakang keberadaan dan misi KPK sebagai super body, sehingga sangat besar ekspektasi rakyat Indonesia terhadap peran KPK dalam upaya penanggulangan korupsi dan kembalinya uang negara yang dicuri oleh para koruptor. Spirit perangkat aturan korupsi adalah menyelamatkan keuangan dan perekonomian negara dengan cara antara lain sebagaimana diatur dalam Pasal 18 ayat (1)b UU No. 31 Tahun 1999 yaitu pembayaran uang pengganti yang jumlahnya sebanyak-banyaknya sama dengan harta benda yang diperoleh dari tindakan pidana korupsi.

Secara yuridis, dalam penjelasan atas Undang-Undang No. 31 Tahun 1999 ditegaskan tentang keuangan Negara yaitu seluruh kekayaan negara dalam bentuk apapun, yang dipisahkan atau yang tidak dipisahkan, termasuk di dalamnya segala bagian kekayaan negara dan segala hak dan kewajiban yang timbul karena : a) berada dalam penguasaan, pengurusan dan pertanggungjawaban pejabat lembaga negara, baik di tingkat pusat maupun daerah; b) Badan Usaha Milik Negera/Badan Usaha Milik Daerah, yayasan, badan hukum, dan perusahaan yang menyertakan modal negara, atau perusahaan yang menyertakan modal pihak ketiga berdasarkan perjanjian dengan negara,

Dari penjelasan tersebut di atas terlihat bahwa keuangan negara mencakup seluruh kekayaan negara berati termasuk uang dan sesuatu yang berharga. Dalam hubungannya dengan tindak pidana korupsi, yang harus dibuktikan adalah adanya kerugian keuangan yang mempunyai hubungan kausal dengan perbuatan terdakwa. Secara teoritik hubungan kausal dapat dilihat dari adanya hubungan dari sebab ke akibat, dari akibat ke sebab, dan dari akibat ke akibat.

Dalam perspektif praktek peradilan, pembuktian adanya kerugian keuangan negara akan didasarkan pada hal-hal yang relevan secara yuridis atau alat-alat bukti yang muncul secara sah di persidangan, antara lain perhitungan atau hasil audit dari pihak yang kompeten, misalnya BPKP atau institusi resmi yang memiliki keahlian dalam hal menentukan adanya kerugian keuangan negara. Bukti atau keterangan yang bersifat instansional akan lebih meyakinkan dibandingkan dengan yang bersifat personal.

Dalam praktek penegakan hukum terhadap korupsi sendiri masih terkandung adanya wacana yang muncul dari adanya bunyi undangundang dan praktek penerapannya. Baik itu menyangkut unsur melawan hukum, ketentuan tentang imposible-nya penerapan hukuman mati bagi koruptor (Pasal 2 ayat 2 UU No. 31/1999), unsur "memperkaya" dan 
"menguntungkan" diri sendiri, orang lain atau korporasi, antara "melawan hukum" (Pasal 2 ayat 1 UU No. 31/1999) ancaman pidana minimal 4 tahun dan "menyalahgunakan kewenangan, kesempatan atau sarana" (Pasal 3) ancaman pidana minimal 1 tahun, dan lain-lain.

Pegawai Negeri atau penyelenggara negara secara yuridis dilarang menerima hadiah atau janji sebagaimana di atur dalam Pasal 11 dan 12 UU No. 20 Tahun 2001 perubahan atas UU NO. 31 tahun 1999, begitu pula Pasal 12B yang mengatur tentang gratifikasi. Secara yuridis Negara Indonesia telah memiliki UU No. 7 Tahun 2006 tentang Pengesahan Konvensi PBB anti Korupsi 2003. Hal ini menunjukkan kelengkapan piranti Undang-Undang Indonesia dalam upaya penanggulangan korupsi. Kendala yang banyak terjadi adalah dalam lapangan praktek penegakan hukumnya baik dalam bentuk tebang pilih, SP3, dan lainnya, hal ini tidak lepas dari penegakan hukum itu sendiri yang tidak pernah berproses di ruang hampa, tetapi selalu terkait dengan variabel-variabel yang mempengaruhinya. Hukum bukan peti kemas yang kosong (empty container), tetapi holoyuridis yang bermuatan nilai-nilai. Keberadaan hukum secara dinamis bergerak secara centripetal ke arah nilai-nilai yang terkandung dalam undang-undang tersebut, juga bergerak secara centrifugal ke arah lingkungan sosial, ekonomi, politik dan budaya yang melingkupinya. Hukum tidak lepas dari struktur rakhaniah masyarakat pendukungnya.

Fenomena korupsi politik yang menjangkiti lembaga kenegaraan mengindikasikan betapa praktek korupsi telah berlangsung secara sistemik. Kemauan politik dan pelaksanaan pemberantasan korupsi dalam pandangan Satjipto Rahardjo diisyaratkan tetap dalam kerangka negara hukum. Kita melakukan perang terhadap korupsi, begitulah teriakan sebagian besar rakyat Indonesia. Namun, kita tidak boleh "menembak" begitu saja orang-orang yang dicurigai sebagai koruptor, sebab ini adalah negara hukum. Maka, perang terhadap korupsi dan koruptor, terhadap premanisme, dan lain-lain, tidak boleh dilakukan di jalan-jalan atau di sembarang tempat. ${ }^{7}$ Identitas negara hukum menanggung konsekuensi diberlakukannya prosedur-prosedur hukum dalam upaya mensikapi, merespon, menanggulangi dan memberantas korupsi. Dalam hubungan peran penegak hukum dalam proses penanggulangan korupsi ini Satjipto mengajukan premis penegakan hukum yang menghasilan kebenaran dan

\footnotetext{
${ }^{7}$ Republika, 7 Juli 2003
} 
keadilan, sebagai lawan dari penegakan hukum yang mencari menang dan tidak menghasilkan kebenaran. Lebih lanjut Satjipto mengelaborasi adanya faktor hati nurani penegak hukum dalam korelasinya dengan tegaknya integritas personal penegak hukum dan kredibilitas institusi peradilan, yang pada gilirannya menyangkut martabat dan masa depan bangsa. Sehingga dalam proses memunculkan hakim-hakim yang baik, pendidikan hukum sebagai kontributor moral dan ketajaman pesan analisis ilmu dapat selalu menyadari relevansi dari kelembagaannya.

Undang-undang merupakan salah satu lembaga sosial yang dipakai untuk menyelesaikan problematika sosial ekonomi dan kasus hukum di dalam masyarakat. Di balik undang-undang ada postulat moral yang melatarbelakangi keberadaan undang-undang. Termasuk di dalamnya adalah apa yang oleh Satjipto Rahardjo dikatakan dengan hal-hal yang bersifat meta yuridis. Pada tingkat peradaban hukum modern kita bisa mengatakan, "tidak ada undang-undang yang tidak cacat," atau "undang-undang itu cacat sejak dilahirkan." Cacat itu bisa besar, sedang atau kecil. Cacat juga bisa kelihatan, tetapi bisa diketahui sesudah undang-undang dijalankan. Masyarakat akan mencari dan menemukan jalannya sendiri untuk bisa selamat di tengah berbagai keburukan yang ada. Ini adalah kekuatan masyarakat yang alami, yang otentik, yang selama ini amat diabaikan dalam pembicaraan mengenai hukum. Gagasan penegakan hukum progresif adalah penegakan hukum yang dijalankan oleh mereka yang tidak ingin melihat Indonesia ambruk dan terpuruk. Itulah semangat, komitmen dan dedikasinya. ${ }^{8}$ Kekuatan masyarakat yang bersifat alami dan otentik yang digambarkan oleh Satjipto adalah nilai-nilai kebenaran moral ada dalam setiap hati nurani individu dan secara sosial dapat membentuk corak, sifat dan karakter masyarakat jika nilai-nilai itu mengkristal dan diterima sebagai pedoman dalam tata pergaulan sosial.

Korupsi politik menghalangi redistribusi kekayaan negara secara adil kepada rakyat, karena pelaku kekuasaan politik mengeksploitasi kewenangan yang diamanatkan oleh rakyat kepadanya untuk melegitimasi pengambilan kekayaan negara yang amoral dan ilegal. Pengadilan yang independen dalam konotasi bebas dari intervensi politik dan pengaruh ekonomis dapat berperan mencegah, menghambat dan membasmi praktek korupsi politik dan memberikan jaminan rasa aman

\footnotetext{
${ }^{8}$ Kompas, 23 Agustus 2003
} 
bagi perekonomian yang sehat serta tumbuhnya kepercayaan bagi investasi domestik dan modal asing.

Budaya masyarakat di Indonesia yang majemuk dan beragam etnis dengan corak budayanya sendiri, mengakibatkan tidak mudah memberi cakupan arti budaya masyarakat Indonesia. Tetapi yang jelas budaya Jawa merupakan salah satu budaya yang ada dalam masyarakat Indonesia. Dalam wacana nasional mengenai maraknya korupsi politik dalam era Orde Baru, seperti yang dipaparkan antara lain oleh harian Kompas yang menyatakan bahwa budaya Jawa memberikan kontribusi yang signifikan terhadap kondisi birokrasi Indonesia yang korup. Apalagi setelah budaya Jawa diinterpretasikan secara salah oleh Soeharto dalam menjalankan kekuasaan. ${ }^{9}$ Apa benar budaya Jawa lahirkan birokrasi yang korup seperti yang dikutip harian Kompas tersebut, tidak sepenuhnya mengandung kebenaran. Apalagi dikaitkan dengan suatu rezim pemerintahan seperti pemerintahan era Soeharto. Korupsi yang terjadi pada zaman Soeharto merupakan korupsi politik yang dilakukan oleh pemegang kekuasaan melibatkan orang-orang berbagai etnis yang berada dalam lingkaran kekuasaan. Korupsi politik seperti yang terjadi pada era Soeharto itu juga terjadi di banyak negara di dunia, baik negara barat atau timur, utara atau selatan. Korupsi politik juga terjadi di negara maju atau negara berkembang, dan terjadi di semua benua di muka bumi ini. Perbedaan korupsi politik antara negara yang satu dengan yang lain adalah intensitasnya, di negara yang sudah terjangkit penyakit korupsi yang kronis, korupsi tersebut telah berlangsung secara sistemik.

\section{Penutup}

Selama ini pemerintah Indonesia dalam upaya menanggulangi korupsi masih lebih banyak mempergunakan upaya-upaya penal dibandingkan dengan upaya-upaya non-penal.

Penanggulangan korupsi politik menuntut aturan hukum (logos) dan prosedur hukum acara (teknologos) yang spesifik, karena menyangkut pelaku kejahatan yang memiliki kekuasaan politik dan/atau pihak yang mempunyai kekuatan ekonomi. Di satu pihak kekuasaan politik atau kekuatan ekonomi berpotensi mengintervensi independensi peradilan, dipihak lain orang yang memiliki kekuasaan politik berkemampuan untuk

\footnotetext{
${ }^{9}$ Kompas, 7 November 2002
} 
menyiasati menyembunyikan alat-alat bukti yang berhubungan dengan kejahatannya.

Konsekuensi logis dari posisi politik pelaku korupsi politik di beberapa negara diberlakukan pembuktian terbalik (shifting burden of proof). Di beberapa negara juga diterapkan pidana maksimal atau pidana seumur hidup bagi terpidana korupsi politik.

Penanggulangan korupsi selain menuntut perangkat keras teknologi, institusi penegak hukum yang berintegritas, juga menuntut tersedianya perangkat lunak yaitu budaya hukum termasuk ideologi hukum dan ideologi penegak hukum. Dalam arti pula penanggulangan korupsi politik di era global menyangkut aspek politik, ekonomi, budaya, hukum, dan internasional.

Adanya kontrol sosial politik yang signifikan dan fungsi penalisasi hukum yang bersukma keadilan dan tegas, merupakan syarat utama dalam upaya mencegah dan menanggulangi korupsi politik.

Sistem penanggulangan korupsi politik lebih tepat mempergunakan sistem penegakan hukum yang legalitas dibandingkan dengan mempergunakan sistem opportunitas. Sistem ini menuntut untuk ditopang oleh tugas penegak hukum yang memiliki mental yang berani menerapkan hukum bagi koruptor politik.

Ada negara yang mempergunakan pembentukan komisi penanggulangan korupsi, ada yang menerapkan shock therapy, ada yang mempergunakan impeachment, dalam menyelesaikan kasus-kasus korupsi politik. Pada gilirannya integritas moral penegak hukum menjadi faktor determinan dalam proses penerapan hukum. Penanggulangan korupsi politik juga menuntut tersedianya perangkat keras teknologi.

Adanya kerangka penanggulangan korupsi politik yang tersistem menuntut adanya semangat yang terintegrasi dengan dinamika sosial politik secara nasional. Upaya tersebut menuntut adanya gerakan pemberantasan korupsi yang memiliki kewibawaan moral. Dalam upaya penanggulangan korupsi politik diperlukan adanya penyelarasan sukma hukum secara runtut dari yang ada dalam ranah kosmos, logos dan teknologos.

Adanya pemahaman hukum secara utuh dalam proses penerapan hukum terhadap korupsi politik, menuntut dihilangkan segala bentuk feodalisasi hukum dan proses penegakan hukum. Dalam upaya penanggulangan korupsi politik yang serius, diperlukan adanya perombakan sistem hukum dan sistem penegakan hukum. 
Kontrol sosial dari masyarakat dalam negara demokrasi, seperti yang diperankan oleh LSM (Lembaga Swadaya Masyarakat), organisasi sosial, perguruan tinggi dan mass media menjadi faktor determinan dalam penanggulangan korupsi politik.

\section{Daftar Pustaka}

Alkostar, Artidjo, Korupsi Politik Di Negara Modern, FH UII Press, Yogyakarta, 2008.

Barbero, Alessandro, The Day of The Barbarians, The Battle That Led The Fall of The Roman Empire, Walker \& Company, New York, 2005

Diamon, larry, The Spirit of Democracy, Times Books, New York, 2008

Fiorina, Morris P, Congress, Keystone of the Washington Establishment, VailBallau Press, Binghamton, New York, 1977.

Hertz, Noreena, Global Capitalims and death of Democracy, the Silent Takeover, harper Collins Publishers Inc, New York, 2003

Hilton, Stanley G \& testa, Anne-Renee, dr, Glass Houses, Shocking Profiles of Congressional Sex Scandals and Other Unofficial Misconduct, St Martin's Paperbacks, New York, 1998

Lewis, Lionel S, When Power Corrupts, Transaction Publisher, New Brunswick, New Jersey, 2000

Rose, Arnold M, The Power Structure Political Pricess in American Society, Oxforsd University Press, Inc, London-New York, 1969.

Sen, Amarta, Development A Freedom, Anchor Books, New York, 1999

Republika, 7 Juli 2003

Kompas, 23 Agustus 2003

Kedaulatan Rakyat, Minggu Pagi, No. 33 tahun ke-60an Minggu II November 2007 